\title{
PENGARUH KINERJA KEUANGAN DAN MAKROEKONOMI TERHADAP RETURN SAHAM PADA SUBSEKTOR MAKANAN DAN MINUMAN PERIODE 2011-2015
}

\author{
Edhi Asmirantho \\ Fakultas Ekonomi Universitas Pakuan, Email: rantho.bs@gmail.com \\ Yudhia Mulya \\ Fakultas Ekonomi Universitas Pakuan, Email: yudhia.mulya@yahoo.co.id \\ Dinar Ardian Firmansyah \\ Fakultas Ekonomi Universitas Pakuan, Email: dinarardianfirmansyah@gmail.com
}

\begin{abstract}
This study is aimed to test the effect of financial performance and macroeconomics variables in explaining stock returns. The study conducts two regression models. The first model included only financial performance as independent variables which consist of current ratio, debt to equity ratio, earnings per share, return on assets, economic value added, inventory turnover, and price to earnings ratio. Then the first model is extended to the second model by adding macroeconomics variables which consist of interest rate and inflation. Pooled least squares regression is applied in this study and all of the assumptions to obtain best linier unbiassed estimator are met. The extended model results in an increase of adjusted $R$-squared value from $46,9 \%$ to $60,84 \%$.
\end{abstract}

Keywords: Financial Performance, Interest Rate, Inflation, Stock Return

\section{PENDAHULUAN}

Rasio keuangan merupakan alat analisis berbasis informasi dari laporan keuangan yang dapat digunakan untuk menilai kesehatan keuangan perusahaan. Kategori rasio keuangan terdiri dari likuiditas, struktur modal, manajemen aset, profitabilitas, dan nilai pasar (Titman, Keown, \& Martin, 2011).

Selain menggunakan pendekatan informasi akuntansi dalam mengukur kinerja keuangan perusahaan, terdapat pendekatan lain yang lebih komprehensif yang dapat digunakan dalam menilai kinerja keuangan perusahaan yaitu Economic Value Added (EVA). Estimasi terhadap nilai EVA menggunakan informasi laba akuntansi yaitu Net Operating Income After Tax (NOPAT), juga menambahkan konsep capital charge yang merupakan hasil perkalian modal investasi perusahaan dengan weighted average cost of capital untuk selanjutnya dikurangkan terhadap NOPAT.

Penelitian ini bertujuan untuk menguji pengaruh variabel kinerja keuangan dan EVA terhadap return saham dengan menggunakan dua buah model regresi. Model pertama menggunakan kinerja keuangan sebagai variabel independen dan return saham sebagai variabel dependen. Model kedua menambahkan variabel makroekonomi sebagai variabel independen ke dalam model pertama untuk mengetahui model manakah yang lebih baik.

\section{KAJIAN LITERATUR}

Current ratio merupakan salah satu indikator likuiditas perusahaan yang menunjukkan kemampuan perusahaan dalam melunasi kewajiban jangka pendek. Penelitian Hasintongan (2010) menghasilkan bahwa current ratio memiliki pengaruh positif terhadap return, namun tidak signifikan. Hasil penelitian Martani, Mulyono, dan Khairurizka (2009) menunjukkan bahwa current ratio tidak berpengaruh terhadap market adjusted return dan abnormal return. Bahkan pada model market adjusted return, current ratio 
memiliki arah pengaruh negatif. Gharaibeh (2014) menguji pengaruh struktur modal dan likuiditas terhadap return saham 15 perusahaan industri yang terdaftar pada pasar modal Amman selama periode 20092012 dan menghasilkan bahwa current ratio berpengaruh negatif dan signifikan terhadap return saham. Utami, Hartoyo, dan Maulana (2015) mengukur likuiditas dengan quick ratio dan dihasilkan bahwa quick ratio memiliki pengaruh negatif dan signifikan terhadap return saham pada perusahaan Indonesia yang bergerak di subsektor konstruksi periode 2010-2014.

Debt to equity ratio (DER) mengukur tingkat penggunaan hutang dalam proporsi pendanaan perusahaan. Semakin tinggi rasio DER menunjukkan semakin tingginya dominasi penggunaan hutang relatif terhadap modal sendiri. Penelitian Hasintongan (2010) menghasilkan bahwa DER memiliki pengaruh negatif terhadap return, namun tidak signifikan. Penelitian Utami, Hartoyo, dan Maulana (2015) menghasilkan bahwa DER memiliki pengaruh negatif dan signifikan terhadap return saham pada perusahaan Indonesia yang bergerak di subsektor konstruksi periode 2010-2014. Sementara, penelitian Tinneke (2007) menyimpulkan bahwa DER tidak berpengaruh terhadap return.

Penelitian Anwaar (2016), Muhammad \& Scrimgeour (2014), dan Haanurat (2013) menghasilkan bahwa return on asset (ROA) berpengaruh positif dan signifikan terhadap return saham. Sementara pada indikator laba lainnya, yaitu earnings per share (EPS) memiliki pengaruh negatif dan signifikan terhadap return (Anwaar, 2016). Namun hasil yang berbeda ditemukan pada penelitian Muhammad \& Scrimgeour (2014) bahwa earnings per share berpengaruh positif dan signifikan terhadap return.

Inventory turnover merupakan indikator untuk mengukur frekuensi pergantian persediaan yang terjadi selama setahun (Keownetal., 2005). Semakin tinggi inventory turnover, maka semakin likuid kinerja persediaan. Penelitian Petcharabul \& Romprasert (2014) menghasilkan bahwa inventory turnover tidak berpengaruh terhadap return saham.

Keterkaitan price to earnings ratio (PER) terhadap return saham dijelaskan dalam penelitian Basu (1997) bahwa saham dengan PER rendah menghasilkan excess return positive relatif terhadap pasar dan saham dengan PER tinggi memiliki kinerja yang kurang baik di pasar (Damodaran, 1994). Penelitian Hasintongan (2010), dan Tinneke (2007) menghasilkan bahwa price to earnings ratio memiliki pengaruh negatif dan signifikan terhadap return saham. Hasil yang berbeda ditemukan dalam penelitian Petcharabul \& Romprasert (2014), dan Utami, Hartoyo, dan Maulana (2015) bahwa price to earnings ratio berpengaruh positif dan signifikan terhadap return saham pada perusahaan yang bergerak pada industri teknologi di pasar modal Thailand.

EVA menyediakan prediktor yang lebih baik terhadap nilai pasar perusahaan karena memiliki kelebihan dibandingkan pengukuran laba seperti NOPAT, laba bersih, atau EPS karena memiliki keterkaitan secara sistematis dengan nilai pasar (O'Byrne \& Stewart, 1996). Market Value Added (MVA) merupakan present value dari seluruh nilai mendatang EVA selama periode umur perusahaan. Dengan demikian, pengelolaan perusahaan yang dilakukan dengan cara meningkatkan EVA akan mengarah pada peningkatan nilai MVA (Keown et al, 2005). Namun demikian, hasil yang berbeda ditemukan pada penelitian Visaltanachoti, Luo, \& Yi Yi (2008), Biddle, Bowen \& Wallace (1997) yang melakukan pengujian terhadap penggunaan EVA sebagai variabel penjelas return saham. Penelitian tersebut menghasilkan bahwa laba memiliki kedudukan yang lebih baik daripada EVA untuk digunakan sebagai variabel penjelas dari return saham. 
Kajian yang meneliti pengaruh EVA terhadap return pada perusahaan go public di Indonesia, diantaranya dilakukan oleh Tinneke (2010) menghasilkan bahwa EVA berpengaruh positif dan signifikan terhadap return saham. Aprilianto (2014), Puspitadewi dan Rahyuda (2016) menemukan bahwa EVA secara parsial tidak berpengaruh terhadap return dan memiliki arah pengaruh positif. Sementara, hasil penelitian Hariani (2010) menghasilkan bahwa EVA berpengaruh negatif dan signifikan terhadap return saham.

Penggunaan variabel tingkat bunga ke dalam model dalam menjelaskan variasi nilai return mengacu pada model multifaktor. Dalam model tersebut, tingkat bunga digunakan sebagai salah satu variabel makroekonomi yang digunakan untuk mengetahui respon return saham yang diakibatkan dari perubahan tingkat bunga (Bodie et al., 2014). Tingkat bunga memiliki keterkaitan dengan return dalam hal biaya modal. Tingginya tingkat bunga akan meningkatkan biaya modal perusahaan dan menyebabkan meningkatnya return yang disyaratkan oleh investor (Tandelilin, 2010). Hasil penelitian Suyanto (2007) pada perusahaan yang tercatat pada Bursa Efek Jakarta subsektor properti periode 20012005 menunjukkan bahwa suku bunga berpengaruh negatif dan signifikan terhadap return saham. Hasil yang sama juga terdapat pada penelitian Suyati (2015) dimana tingkat suku bunga berpengaruh negatif dan signifikan terhadap return saham pada sektor properti di Bursa Efek Indonesia. Sementara, pada penelitian Dwita dan Rahmidani (2012) dihasilkan bahwa tingkat bunga tidak berpengaruh terhadap return saham pada sektor restoran, hotel dan pariwisata.

Inflasi yang tinggi menyebabkan penurunan daya beli dan mengurangi tingkat pendapatan riil investor, sehingga merupakan sinyal negatif bagi investor (Tandelilin, 2010). Penggunaan variabel inflasi dalam model mengacu pada model multifaktor Chen, Roll, dan Ross dimana inflasi digunakan sebagai salah satu variabel makroekonomi yang mempengaruhi return saham (Bodie et al., 2014). Hasil penelitian Suyanto (2007) pada perusahaan yang tercatat pada Bursa Efek Jakarta subsektor properti periode 2001-2005 menunjukkan bahwa inflasi tidak berpengaruh terhadap return saham. Hasil yang berbeda dalam penelitian Dwita dan Rahmidani (2012), dan Suyati (2015) bahwa inflasi berpengaruh negatif dan signifikan terhadap return saham pada sektor restoran, hotel dan pariwisata.

Berdasarkan telaah literatur diatas maka rumusan hipotesis dalam penelitian ini sebagai berikut.

$\mathrm{H}_{1}$ : Current ratio (CR) berpengaruh positif dan signifikan terhadap return saham.

$\mathrm{H}_{2}$ : Debt to equity ratio (DER) berpengaruh negatif dan signifikan terhadap return saham.

$\mathrm{H}_{3}$ : Earnings per share (EPS) berpengaruh positif dan signifikan terhadap return saham. $\mathrm{H}_{4}$ : Return on assets (ROA) berpengaruh positif dan signifikan terhadap return saham. $\mathrm{H}_{5}$ : Economic value added (EVA) berpengaruh positif dan signifikan terhadap return saham.

$\mathrm{H}_{6}$ : Inventory turnover (IT) berpengaruh positif dan signifikan terhadap return saham. $\mathrm{H}_{7}$ : Price to earnings ratio (PER) berpengaruh positif dan signifikan terhadap return saham. $\mathrm{H}_{8}$ : Suku bunga SBI (SBI) berpengaruh negatif dan signifikan terhadap return saham.

$\mathrm{H}_{9}$ : Inflasi (INF) berpengaruh negatif dan signifikan terhadap return saham.

$H_{10}$ : CR, DER, EPS, EVA, ROA, IT, dan PER berpengaruh terhadap return saham.

$H_{11}$ : CR, DER, EPS, EVA, ROA, IT, PER, SBI, dan INF berpengaruh terhadap return saham.

\section{METODE PENELITIAN}

Penelitian menggunakan data sekunder pada perusahaan go public yang berada dalam subsektor makanan dan minuman 
periode 2011 sampai dengan 2015. Jenis data yang digunakan adalah data panel, yaitu gabungan data lintas perusahaan sebanyak 12 perusahaan dan lintas waktu sebanyak 5 tahun atau terdiri dari 60 observasi. Berdasarkan bentuk data tersebut, maka model regresi yang digunakan dalam penelitian ini adalah regresi panel. Uji Chow dilakukan untuk memilih model yang terbaik antara model Pooled Least Square dengan Fixed Effect Model. Selain itu, uji asumsi klasik juga dilakukan yang terdiri dari uji normalitas, multikolinearitas, heteroskedastisitas, dan autokorelasi. Pengolahan data, pengujian model regresi panel, dan uji normalitas dilakukan dengan menggunakan program Eviews 8. Uji heteroskedastisitas, multikolinearitas, dan autokorelasi dilakukan dengan menggunakan program STATA.

Model yang digunakan untuk menguji hipotesis dalam penelitian ini terdiri dari 2 model. Model 1 menggunakan kinerja keuangan sebagai variabel independen sebagai berikut:

$$
\begin{array}{rl}
R_{i t}=\alpha_{i}+\beta_{1 i} & C R_{i t}+\beta_{2 i} D E R_{i t}+\beta_{3 i} E P S_{i t} \\
& +\beta_{4 i} E V A_{i t}+\beta_{5 i} R O A_{i t} \\
& +\beta_{6 i} I T_{i t}+\beta_{7 i} P E R_{i t} \\
\text { Model } 2 \text { menambahkan variabel }
\end{array}
$$
makroekonomi yang terdiri dari suku bunga SBI dan tingkat inflasi ke dalam model 1. Model 2 disajikan sebagai berikut:

$$
\begin{array}{rl}
R_{i t}=\alpha_{i}+\beta_{1 i} & C R_{i t}+\beta_{2 i} D E R_{i t}+\beta_{3 i} E P S_{i t} \\
& +\beta_{4 i} E V A_{i t}+\beta_{5 i} R O A_{i t} \\
& +\beta_{6 i} I T_{i t}+\beta_{7 i} P E R_{i t} \\
& +\beta_{8 i} S B I_{i t}+\beta_{9 i} I N F_{i t}
\end{array}
$$

$\mathrm{R}_{\mathrm{it}}$ adalah excess return saham i. Excess return diperoleh dengan cara menghitung selisih antara return saham i terhadap ratarata return bebas resiko. CR adalah current ratio yang dihitung dari aset lancar dibagi terhadap hutang lancar. DER adalah debt to equity ratio yang dihitung dengan cara membagi total kewajiban terhadap total ekuitas. EPS adalah earnings per share yang dihitung dari laba setelah pajak dibagi dengan jumlah saham beredar. EVA adalah economic value added yang dihitung berdasarkan rumus:

$E V A=[$ return on invested capital biaya modal]x invested capital.

ROA adalah return on asset yang dihitung dengan membagi laba setelah pajak terhadap total aset. PER adalah price earnings ratio yang dihitung dari harga per lembar saham dibagi dengan laba per lembar saham. SBI adalah rata-rata tingkat bunga sertifikat bank indonesia per tahun. INF adalah tingkat inflasi rata-rata per tahun.

\section{HASIL PENELITIAN DAN PEMBAHASAN}

Rata-rata return saham dalam subsektor makanan dan minuman sebesar 16,95\% dengan nilai standar deviasi sebesar $64,76 \%$. Hal ini menunjukkan bahwa data return memiliki variasi nilai yang tinggi. Variasi nilai yang tinggi juga terdapat pada variabel independen EPS, ROA, PER, dan EVA. Sementara, nilai rata-rata pada variabel independen $C R, D E R, S B I$, dan inflasi lebih tinggi dari standar deviasinya. Dengan demikian, nilai rata-rata pada variabelvariabel tersebut dapat mewakili keseluruhan data.

Kemampuan likuiditas pada subsektor makanan dan minuman yang diukur dengan current ratio memiliki nilai rata-rata 2,017. $\mathrm{Hal}$ ini menunjukkan kinerja yang baik pada likuiditas. Tingkat penggunaan hutang yang diukur dengan debt to equity ratio memiliki nilai rata-rata sebesar 0,98 yang berarti tingkat penggunaan ekuitas pada subsektor makanan dan minuman masih lebih dominan daripada hutang. Dari segi profitabilitas, rata-rata nilai earnings per share sebesar Rp219,43 per lembar saham dan rata-rata tingkat pengembalian aset yang diukur dengan return on assets sebesar $11,63 \%$. Rasio kelipatan harga saham terhadap laba per lembar saham menunjukkan rata-rata sebesar $2.448,96$ kali. Rata-rata nilai tambah ekonomi 
memiliki nilai positif sebesar Rp860.734,7 juta. Variabel makroekonomi yang diukur dengan suku bunga $\mathrm{SBI}$ dan inflasi menunjukkan bahwa rata-rata suku bunga SBI sebesar $6,78 \%$ dan rata-rata tingkat inflasi sebesar $5,89 \%$ selama periode penelitian. Hasil statistik deskriptif disajikan pada tabel 1.

Selanjutnya dilakukan pengujian kesesuaian model dengan menggunakan uji Chow. Uji Chow dilakukan untuk menguji hipotesis nol bahwa menggunakan model pooled least square. Hasil uji chow disajikan pada tabel berikut ini.

Tabel1: Uji Chow

\begin{tabular}{|c|c|c|c|c|}
\hline Model & $\begin{array}{c}\text { Effect } \\
\text { Test }\end{array}$ & Statistic & d.f. & Prob. \\
\hline 1 & $\begin{array}{c}\text { Cross- } \\
\text { section } \\
\mathrm{F}\end{array}$ & 1.016866 & $(11,41)$ & 0.4493 \\
\hline 2 & $\begin{array}{c}\text { Cross- } \\
\text { section } \\
\mathrm{F}\end{array}$ & 1.187487 & $(11,39)$ & 0.3271 \\
\hline
\end{tabular}

Hasil uji Chow menunjukkan nilai probabilitas $\mathrm{F}$ lebih besar dari $\alpha=0,05$ pada kedua model, sehingga disimpulkan bahwa model pooled least square lebih sesuai untuk digunakan. Berdasarkan hasil pengolahan data, model regresi pooled least square dengan menggunakan pembobotan cross section weight memberikan hasil paling baik pada penelitian ini.

Setelah diperoleh model regresi yang terbaik, selanjutkan dilakukan uji asumsi klasik. Uji Jarque-Bera digunakan untuk menguji hipotesis nol bahwa nilai residu menyebar normal. Nilai probabilitas yang dihasilkan dari uji Jarque-Bera sebesar 0,2656 pada model 1 dan 0,2407 pada model 2. Dengan demikian, nilai residu berdistribusi normal pada kedua model. Hasil uji normalitas disajikan pada gambar berikut.
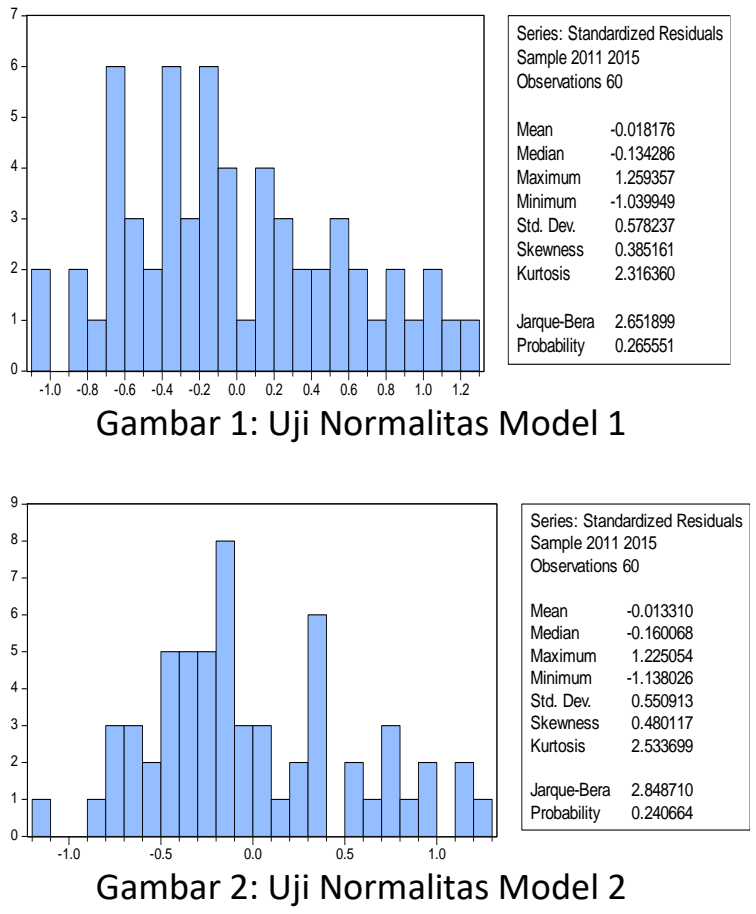

Uji VIF digunakan untuk mendeteksi adanya gejala multikolinearitas. Hasil uji VIF menunjukkan bahwa seluruh variabel penelitian memiliki nilai VIF di bawah 10 di kedua model. Dengan demikian, data yang digunakan terbebas dari masalah multikolinearitas.

Tabel 2: Uji Multikolinearitas

\begin{tabular}{|l|c|c|}
\hline Variabel & VIF Model 1 & VIF Model 2 \\
\hline CR & 2.29 & 2.55 \\
\hline DER & 2.12 & 2.36 \\
\hline EPS & 1.95 & 2.03 \\
\hline ROA & 2.63 & 2.66 \\
\hline EVA & 1.48 & 1.52 \\
\hline IT & 1.20 & 1.20 \\
\hline PER & 3.07 & 3.25 \\
\hline SBI & - & 2.14 \\
\hline INF & - & 1.90 \\
\hline
\end{tabular}

Uji heteroskedastisitas dilakukan untuk menguji apakah nilai residu memiliki varian yang sama. Uji Breusch-Pagan / CookWeisberg digunakan untuk menguji hipotesis nol bahwa nilai residu memiliki varian konstan (homogen). Hasil pengujian menunjukkan nilai probabilitas sebesar 
0,7270 pada model 1 dan 0,5221 pada model 2. Hal ini berarti nilai residu sudah homogen pada kedua model.

Tabel3: Uji Heterokedastisitas

\begin{tabular}{|l|c|}
\hline $\begin{array}{l}\text { Breush-Pagan/Cook- } \\
\text { Weisberg test }\end{array}$ & Prob $>$ Chi2 \\
\hline Model 1 & 0.7270 \\
\hline Model 2 & 0.5221 \\
\hline
\end{tabular}

Uji autokorelasi dilakukan untuk menguji apakah terjadi korelasi antara observasi yang berturut-turut sepanjang waktu. Uji Wooldridge test untuk menguji hipotesis nol yaitu tidak terdapat autokorelasi. Uji tersebut menghasilkan nilai probabilitas sebesar 0,3523 pada model 1 dan 0,4825 pada model 2. Dengan demikian, tidak terdapat autokorelasi pada kedua model.

Tabel4: Uji Autokorelasi

\begin{tabular}{|l|c|}
\hline Woolridge test & Prob > Chi2 \\
\hline Model 1 & 0.3523 \\
\hline Model 2 & 0.4825 \\
\hline
\end{tabular}

Uji statistik $F$ pada kedua model menghasilkan nilai probabilitas sebesar 0,000001 pada model 1 dan 0,000000 pada model 2 yang menunjukkan bahwa kedua model dapat digunakan untuk menganalisis return secara signifikan. Model 1 memiliki nilai adjusted $R$-squared sebesar $46,9 \%$ yang berarti variasi return dapat dijelaskan oleh variasi $C R, D E R, E P S, E V A, R O A, I T$, dan PER sebesar $46,9 \%$. Sementara pada model 2 , dengan menambahkan variabel makroekonomi, yaitu suku bunga SBI dan tingkat inflasi, nilai adjusted R-squared meningkat menjadi $60,84 \%$. Hal ini menunjukkan adanya determinasi yang kuat dimana variasi variabel return dapat dijelaskan oleh variasi variabel kinerja keuangan yang terdiri dari CR, DER, EPS, EVA, ROA, IT, PER dan variasi variabel makroekonomi yang terdiri dari suku bunga
SBI, dan inflasi sebesar $60,84 \%$. Hasil model regresi disajikan pada tabel 2 .

Tabel5: Hasil Regresi Panel Least Square Model 1

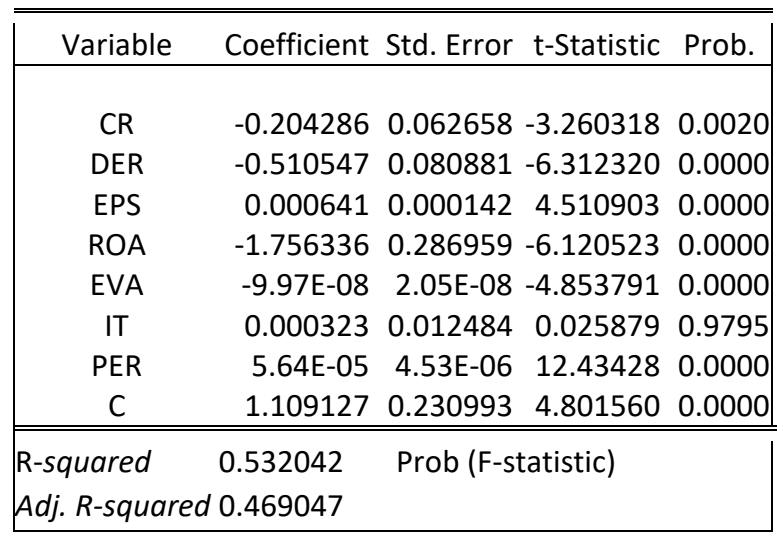

Tabel6: Hasil Regresi Panel Least Square Model 2

\begin{tabular}{|c|rrrr|}
\hline Variable & Coefficient & Std. Error t-Statistic & Prob. \\
\hline CR & -0.189694 & $0.049910-3.800725$ & 0.0004 \\
DER & -0.446606 & $0.070616-6.324472$ & 0.0000 \\
EPS & 0.000583 & $6.83 \mathrm{E}-05$ & 8.538331 & 0.0000 \\
ROA & -1.528149 & $0.279739-5.462772$ & 0.0000 \\
EVA & $-8.31 \mathrm{E}-08$ & $2.19 \mathrm{E}-08-3.796010$ & 0.0004 \\
IT & 0.004873 & 0.012108 & 0.402508 & 0.6890 \\
PER & $4.78 \mathrm{E}-05$ & $3.64 \mathrm{E}-06$ & 13.12235 & 0.0000 \\
INF & -1.702009 & $3.661333-0.464860$ & 0.6440 \\
SBI & -19.43961 & $5.856452-3.319349$ & 0.0017 \\
C & 2.381285 & 0.322024 & 7.394738 & 0.0000 \\
\hline \hline$R$-squared & 0.668171 & Prob (F-statistic) & 0.000000 \\
Adj. $R$-squared & 0.608441 & & & \\
\hline
\end{tabular}

Hasil pengujian hipotesis secara parsial pada model 1 menunjukkan bahwa current ratio, debt to equity ratio, earnings per share, return on assets, economic value added, dan price to earnings ratio berpengaruh signifikan terhadap return. Inventory turnover tidak berpengaruh terhadap return. Sementara, pada model 2 dengan menambahkan variabel makroekonomi yaitu suku bunga SBI dan tingkat inflasi, variabel kinerja keuangan yang berpengaruh terhadap return masih sama sebagaimana yang telah dihasilkan pada model 1. Inventory turnover juga tidak 
berpengaruh terhadap return pada model 2 . Variabel makroekonomi yang berpengaruh signifikan terhadap return adalah suku bunga SBI. Inflasi tidak berpengaruh terhadap return. Arah pengaruh dari kedua model juga menunjukkan konsistensi dimana tidak ada perubahan tanda arah pengaruh pada koefisien current ratio, debt to equity ratio, earnings per share, economic value added, return on assets, inventory turnover, dan price to earnings ratio di kedua model.

Current ratio berpengaruh negatif dan signifikan terhadap return dengan koefisien sebesar -0,204286 pada model 1 dan 0,189694 pada model 2. Hal ini berarti setiap penurunan likuiditas sebesar $1 \%$ maka nilai return akan meningkat sebesar $20,43 \%$ pada model 1 dan 18,67\% pada model 2. Hasil penelitian ini sejalan dengan Gharaibeh (2014) dan Utami, Hartoyo, dan Maulana (2015). Namun, hasil penelitian tidak sejalan dengan hipotesis. Sehingga $H_{1}$ bahwa Current ratio (CR) berpengaruh positif dan signifikan terhadap return saham ditolak.

Debt to equity ratio berpengaruh negatif dan signifikan terhadap return dengan koefisien sebesar $-0,510547$ pada model 1 dan -0,446606 pada model 2 . Interpretasi dari angka tersebut adalah setiap penurunan debt to equity ratio sebesar $1 \%$ maka return akan meningkat sebesar 51,05\% pada model 1 dan 44,66\% pada model 2. Hasil penelitian ini sejalan dengan penelitian Utami, Hartoyo, dan Maulana (2015). Hasil penelitian juga mendukung hipotesis. Sehingga, $\mathrm{H}_{2}$ bahwa debt to equity ratio (DER) berpengaruh negatif dan signifikan terhadap return saham diterima.

Earning per share berpengaruh positif dan signifikan terhadap return dengan koefisien sebesar 0,000641 pada model 1 dan 0,000583 pada model 2 sehingga dapat diinterpretasikan bahwa setiap kenaikan $1 \%$ pada EPS maka return akan naik sebesar $0,0641 \%$ pada model 1 dan $0,0583 \%$ pada model 2. Hasil penelitian ini sejalan dengan penelitian Muhammad \& Scrimgeour (2014). Hasil penelitian juga mendukung hipotesis. Sehingga, $\mathrm{H}_{3}$ bahwa Earnings per share (EPS) berpengaruh positif dan signifikan terhadap return saham diterima.

Return on asset berpengaruh negatif dan signifikan terhadap return saham dengan koefisien sebesar $-1,756336$ pada model 1 dan -1,528149 pada model 2 . Sehingga dapat diinterpretasikan bahwa setiap penurunan $1 \%$ pada ROA, maka return akan meningkat sebesar $175,63 \%$ pada model 1 dan 152,81\% pada model 2. Hasil penelitian ini tidak sejalan dengan penelitian Anwaar (2016), Muhammad \& Scrimgeour (2014), dan Haanurat (2013). Hasil penelitian juga tidak sejalan dengan hipotesis, sehingga $\mathrm{H}_{4}$ bahwa Return on assets (ROA) berpengaruh positif dan signifikan terhadap return saham ditolak.

Economic value added (EVA) berpengaruh negatif dan signifikan terhadap return dengan koefisien sebesar -9,97E-08 pada model 1 dan -8,31E-08 pada model 2 . Hal ini berarti setiap penurunan $1 \%$ pada EVA maka return akan meningkat sebesar $0,00000997 \%$ pada model 1 dan $0,00000831 \%$ pada model 2 . Hasil penelitian ini sejalan dengan penelitian Hariani (2010) yang menemukan adanya pengaruh negatif dan signifikan pada EVA terhadap return pada saham-saham perusahaan yang terdaftar dalam Jakarta Islamic Index di Bursa Efek Indonesia periode 2005-2007. Namun, hasil penelitian tidak sejalan dengan hipotesis. Sehingga, $\mathrm{H}_{5}$ bahwa Economic Value Added (EVA) berpengaruh positif dan signifikan terhadap return saham ditolak.

Inventory turnover tidak berpengaruh terhadap return saham. Hasil ini sejalan dengan penelitian Petcharabul \& Romprasert (2014). Hasil penelitian tidak sejalan dengan hipotesis. Sehingga, $\mathrm{H}_{6}$ bahwa inventory turnover (IT) berpengaruh positif dan signifikan terhadap return saham ditolak. 
Price to earning ratio berpengaruh positif dan signifikan terhadap return dengan koefisien sebesar 5,64E-05 pada model 1 dan 4,78E-05 pada model 2. Hal ini berarti setiap kenaikan PER sebesar $1 \%$, maka return akan meningkat sebesar $0,00564 \%$ pada model 1 dan $0,00478 \%$ pada Model 2 . Hasil ini sejalan dengan penelitian Petcharabul \& Romprasert (2014), dan Utami, Hartoyo, dan Maulana (2015). Hasil penelitian sejalan dengan hipotesis. Sehingga, $\mathrm{H}_{7}$ bahwa Price to earnings ratio (PER) berpengaruh positif dan signifikan terhadap return saham diterima.

Suku bunga Sertifikat Bank Indonesi (SBI) berpengaruh negatif dan signifikan terhadap return dengan koefisien -19,43961. Hal ini berarti setiap penurunan $1 \%$ pada suku bunga $\mathrm{SBI}$, maka return akan meningkat sebesar 1.943,96\%. Hasil penelitian ini sejalan dengan penelitian Suyanto (2007) dan Suyati (2015). Hasil penelitian mendukung hipotesis. Sehingga, $\mathrm{H}_{8}$ bahwa suku bunga $\mathrm{SBI}(\mathrm{SBI})$ berpengaruh negatif dan signifikan terhadap return saham diterima.

Inflasi tidak berpengaruh terhadap return. Hasil penelitian ini sejalan dengan penelitian Suyanto (2007). Dengan demikian, $\mathrm{H}_{9}$ bahwa inflasi (INF) berpengaruh negatif dan signifikan terhadap return saham ditolak.

\section{KESIMPULAN}

Hasil penelitian menunjukkan bahwa variasi return saham dapat dijelaskan lebih baik pada model yang menggunakan variabel makroekonomi, selain variabel kinerja keuangan. Hal tersebut diindikasikan dengan meningkatnya adjusted R-squared pada model yang mengakomodir variabel makroekonomi.

Perbaikan yang perlu dilakukan pada penelitian selanjutnya adalah menggunakan proksi alternatif lain atau memperbaiki cara pengukuran pada variabel current ratio, return on asset, EVA, inventory turnover, dan inflasi serta menambahkan penggunaan variabel makroekonomi lainnya seperti PDB, nilai tukar.

\section{DAFTAR PUSTAKA}

Anwaar, Maryyam. Impact of Firms' Performance on Stock Returns (Evidence from Listed Companies of FTSE-100 Index London, UK). Global Journal of Management and Business Research: Accounting and Auditing. Volume 16 Issue 1. 2016. Online ISSN: 2249-4588. Print ISSN: 0975-5853.

Aprilianto, Robi. Analisis Superioritas Pengaruh EVA, EPS, ROA atau ROE terhadap Return Saham. Thesis. Program Studi Magister Manajemen. Fakultas Ekonomika dan Bisnis. Universitas Gadjah Mada. 2014.

Biddle, Gary C., Robert M. Bowen, and James S. Wallace. Does EVA ${ }^{\circledR}$ Beat Earnings? Evidence on Associations with Stock Returns and Firms Values. Journal of Accounting \& Economics 24 (1997) 301-336.

Bodie, Zvi, Alex Kane, Alan J. Marcus, and Ravi Jain. Investments, Asia Global Edition. McGraw Hill Education. Ninth Edition. 2014.

Damodaran, Aswath. Damodaran on Valuation Security Analysis for Investment and Corporate Finance. John Wiley \& Sons, Inc. 1994.

Dwita, Vidyarini dan Rose Rahmidani. Pengaruh Inflasi, Suku Bunga dan Nilai Tukar terhadap Return Saham Sektor Restoran, Hotel dan Pariwisata. Jurnal Kajian Manajemen Bisnis. Volume 1, Nomor 1, Maret 2012.

Gharaibeh, Adnan. Capital Structure, Liquidity, and Stock Returns. European Scientific Journal. September Edition Vol. 10 No. 25. ISSN: 1857-7881 (Print). E-ISSN 1857-7431.

Haanurat, A. Ifayani. Pengaruh Karakteristik Perusahaan dan Ekonomi makro terhadap Return Saham Syariah yang 
Listing di Jakarta Islamic Index. Jurnal Manajemen dan Bisnis. ISSN: 20870701. Vol. 3 No. 2 April 2013.

Hariani, Lilik Sri. Analisis Pengaruh Economic Value Added (EVA) dan Rasio Keuangan Terhadap Return Saham Syariah. Jurnal Ekonomi Modernisasi Fakultas Ekonomi Universitas Kanjuruhan Malang. E-ISSN: 25024078. Vol. 6 No. 1. 2010.

Hasintongan, Ronald Rudy. Analysis of The Influence of Accounting Variables on Stock Returns, Bachelor Thesis. Faculty of Economics and Business. University of Amsterdam.

Keown, Arthur J, John D. Martin, J. William Petty, and David F. Scott, Jr. Financial Management Principles and Applications. Pearson Prentice Hall. Tenth Edition. 2005.

Martani, Dwi, Mulyono, dan Rahfiani Khairurizka. The Effect of Financial Ratios, Firm Size, and Cash Flow From Operating Activities in The Interim Report to Stock Return. Chinese Business Review. ISSN 1537-1506, USA, Volume 8 No. 6 (Serial No. 72). 2009.

Muhammad, Noor and Frank Scrimgeour. Stock Returns and Fundamentals in the Australian Market. Asian Journal of Finance \& Accounting. ISSN 1946052X. 2014. Vol. 6. No. 1.

O'Byrne, Stephen F and Stern Stewart \& Co., EVA $^{\circledR}$ and Market Value. Journal of Applied Finance. Volume 9 Number 1. 1996.

Petcharabul, Pinradee, and Suppanunta Romprasert. Technology Industry of Financial Ratios and Stock Returns. Journal of Business and Economics. ISSN 2155-7950, USA. 2014. Volume 5 No. 5, pp. 739-647.

Puspitadewi, Cokorda Istri Indah dan Henny Rahyuda. Pengaruh DER, ROA, PER , dan EVA terhadap Return Saham Pada Perusahaan Food and Beverage di BEI.
E-Jurnal Manajemen Unud. Vol. 5, No. 3. 2016. 1429-1456. ISSN: 2302-8912.

Suyanto. 2007. Analisis Pengaruh Nilai Tukar Uang, Suku Bunga dan Inflasi Terhadap Return Saham Sektor Properti yang Tercatat di Bursa Efek Jakarta Tahun 2001-2005. Thesis. Program Pasca Sarjana Universitas Diponegoro.

Tandelilin, Eduardus. Portofolio dan Investasi Teori dan Aplikasi. Edisi Pertama. Kanisius. 2010.

Tinneke, Raden. Analisis Pengaruh Economic Value Added (EVA) dan Faktor-Faktor Fundamental Perusahaan Lainnya Terhadap Return Saham. Thesis. Program Studi Magister Manajemen Universitas Diponegoro. 2007.

Titman, Sheridan, Arthur J. Keown, and John D. Martin. Financial management Principles and Applications. Eleventh Edition. Pearson Prentice Hall. 2011.

Utami, Widya Retno, Sri Hartoyo, dan Tubagus Nur Ahmad Maulana. The Effect of Internal and External Factors on Stock Return: Empirical Evidence from the Indonesian Construction Subsector. Asian Journal of Business and Management ISSN: 2321-2802. Volume 03. 2015.

Visaltanachoti, Nuttawat, Robin Luo, and Yi Yi. Economic Value Added (EVA ${ }^{\circledR}$ ) and Stock Returns. Asian Academy of Management Journal of Accounting and Finance. Vol. 4, No. 2, 21-41, 2008. 